\title{
CAPITALIST RICE FARMING AND LAND ALLOCATION IN NORTHERN GHANA
}

Piet Konings

The recent introduction of capitalist rice farming in the Gbedembilisi Valley - a river valley located in the south-east of the Builsa Traditional Area in the Upper Region of Ghana - has given rise to the emergence of a small class of mainly stranger and partly absentee farmers within local peasant communities. They have been attracted to large-scale, mechanized rice production by high state subsidies and relatively easy access to loans from the banks. This class of capitalist rice farmers has been highly dependent on local peasant communities for the allocation of land suitable for large-scale, mechanized rice production and for the supply of (casual) labor. It will be shown in this study that land allocation to capitalist rice farmers has resulted in: (i) various abuses of "customary" land law by both local chiefs and stranger farmers; (ii) a protracted conflict between local peasant communities, on the one hand, and stranger farmers and the state, on the other, about control over Builsa lands, the so-called Gbedembilisi Valley Dispute; and (iii) an attempt by the Builsa Traditional Council (BTC) to effect changes in the "customary" land law in order to "regulate" land allocation to capitalist rice farmers.

The study is based on fieldwork in the Gbedembilisi Valley during the $1979 / 80$ farming season. Various methods were used to gather the data and to increase their reliability. The most important were: consultation of written material in several libraries, archives and offices in Ghana; unstructured (or partially structured) interviews with relevant informants at the local, district, regional and national level; and in particular, participant observation at the local level. In addition, extensive surveys were held at the local level (see Konings 1983: 20-23).

This article documents, first, the changes effected in Builsa customary land law during the colonial period and the superimposition of a "modern" land law system; next, it describes the development of capitalist rice farming in the Gbedembilisi Valley and the system of land allocation by local chiefs to capitalist rice 


\section{JOURNAL OF LEGAL PLURALISM 1984}

farmers; and, finally, it analyzes the so-called Gbedembilisi Valley Dispute and the subsequent attempt to bring about changes in the customary land law in order to adapt it to the realities of capitalist rice farming in the Gbedembilisi Valley.

Pre-Colonial Builsa Socio-Economic Organization and the Land Tenure System

Recently the Bullsa socio-economic organization, which shows some striking similarities with that of the neighboring Tallensi (Fortes 1945, 1949), has been studied by a group of German ethnologists (Schott 1970, 1977, 1980a and b; Kröger 1978, 1982; and Heermann 1981). Builsa society was a segmentary, patrilineal society, like Tallensi society. Chieftainship seems to have been unknown till immigrants imposed it on at least some of the autonomous settlements in the area (Schott 1977). However, it would appear that these newly appointed chiefs wielded very little actual political and legal power during the pre-colonial era. Social control, sanctioned by religion, continued to be exercised by the compound heads and clan elders, in particular the teng-nyono (pl. teng-nyam), the "lord" or "priest" of the Earth (Schott $1980 \mathrm{a}$ and b; Kröger 1982). The teng-nyono, usually the most senior elder of the oldest resident clan section, was called upon to make sacrifices to the Earth (teng) whenever the settlement was threatened by drought, a locust invasion, pestilence, or war. His duties included arbitration in the frequent conflicts at both intra-clan and extra-clan levels, because these were believed "to pollute the Earth".

Every compound in the Builsa dispersed settlements constituted an economically self-sufficient production and consumption unit under the command of the compound head, usually the most senior male member of the household. The compound head could command the labor power of all household members and dispose of the surplus; in return, he was obliged to provide equitably for the needs and wants of the household members. The most important economic activity was agriculture, mainly for subsistence purposes (though a small surplus was often marketed). The use of rudimentary agricultural tools like the hoe, axe and cutlass always restricted agricultural production. In addition to farming, the Builsa kept poultry, sheep, goats and cattle for domestic consumption, for sale (in particular when food supplies got exhausted), and for religious purposes (sacrifices). Cattle were particularly valued and constituted the main source of social differentiation among the Builsa. During the agricultural off-season, the Bullsa were mostly involved in hunting, trapping and fishing, to supplement the family food supplies and for trade. Many Builsa, moreover, were specialists in various kinds 


\section{CAPITALIST FARMING AND LAND ALLOCATION IN GHANA Piet Konings}

of crafts including weaving, pottery, and leather and metal
works (Akanko 1974; Heermann 1981).

These economic activities made the Builsa largely dependent on land. Rights to land were handed down in the unwritten code of the Builsa land tenure system. According to Builsa beliefs, land is a goddess (the Earth) and belongs to the spirit (wen) of the ancestors. The living enjoy only usufructuary rights. The tengnyam, lineage-elders and compound heads, act as custodians of the ancestral lands.

Uncultivated lands - as well as rivers, forests, roads etc. - fell under the direct control of the teng-nyono. On such land, every member of the community was free to graze his cattle, to gather fruits and woods, and to fish and hunt. The teng-nyono could allocate pieces of these uncultivated lands to anyone - whether community member or stranger - to sustain himself and his dependants. Land allocated in this way was not paid for, except for the customary offering of "kolanuts and tobacco". Land could never be sold, not only because it was abundant in the Builsa area and had not acquired any commercial value as yet, but also because it was held to belong to the ancestors and as such had to be passed on to the future generations intact. Moreover, the sale of land was regarded as an act that might incur the wrath of the Goddess of the Earth and hence cause epidemics and deaths. While land allocated to members of the community became, following the teng-nyono's performance of the necessary rites, their inalienable and heritable "property", strangers, on ified other hand, only enjoyed usufructuary rights for an unspecified period subject to good behavior and observance of the norms of the community. In principle, the strangers' usufructuary rights could always be revoked. After harvest, both community members and strangers were expected to hand over a small portion of their produce to the teng-nyono as a token of appreciation.

The lineage-elders controlled the land inhabited and cultivated by their ancestors. Membership of a lineage entitled a family, lineage allocated by the lineage was no longer being cultivated could be needed by lineage elder to another family. Lineage land not needed by lineage members could sometimes be given to of time following ther oven to strangers for a specific period of time following the presentation of the customary offering of "kola and tobacco" (as well as a small portion of the produce).

Today, still, the family-head may allocate some family land to individual members of the family (and sometimes even to persons outside the family). Generally speaking, land is allocated only to 


\section{JOURNAL OF LEGAL PLURALISM 1984}

men. However, unmarried women and divorcees may be given a
portion of family land which they then cultivate independently; Female usufructuary rights are narden from their husbands. in case of death or divorce (Heermann heritable, but are dissolved

Though lineage and family land was controlled by the always to be consulted for his respectively, the teng-nyono had ly land was allocated to strangers whenever lineage or famiwished to establish a new compound Even family members who permission from the teng-nyompound on family land had to ask and family land could not be settled. If conflicts about lineage ly, the teng not be setled within the lineage and fage which would byono would be called upon to make line and famiteng-nyono binding on both interested parties decision pliancenyono had various sanctions at hisested parties (and the pliance with his decision, such as his disposal to enforce comand its re-allocation to a third person).

Changes brought about in the Builsa Socio-Economic Organization

brought about various colonial rule in Northern Ghana (1902) nization and the customary land in Builsa socio-economic orga"modern" land law on top of the "neo-traditional" and imposed a

\section{a. Changes effected in Builsa Socio-Economic Organization}

The colonial administration effected two (in Builsa socio-economic organization two (interrelated) changes in to our study:

- It appointed chiefs in the Builsa settlements where the instistren of chieftainship had never existed where the insticould carry the power of the existing chiefs sously and This respon out their colonial respon ibility so that they and the rensibility entailed the control of local subply of labor power, most of local communities to the collection of "direct rule" (1902-1932) during the minor collection of taxes and the exercise minor matters during the period the Sandem 1979). In 1912 it elevated the "indirect rule" the Sandemnab, to the office of parad the chief of Sandema, Builsa area. Through this creation of under the paramountcy of the of a Builsa (native) state autonomous Builsa settlements were 
fact marked the beginning of the growth of an ethnic consciousness among the Builsa (Konings 1981a).

- It transferred the Builsa area, as the whole of Northern Ghana, into a labor reserve for the South Ghanaian export economy (Songsore 1979; Plange 1979; Konings 198la and b). Initially, coercion by the colonial authorities - assisted by the chiefs - proved necessary to extract labor from the Builsa peasant communities (Thomas 1973). Various kinds of administrative measures (like starving the Builsa area of development funds) and the growing need for cash created by the colonial economy were, however, among the most important factors promoting a "voluntary" flow of Builsa labor to the South. At the end of the colonial period about $30 \%$ of all occupied Builsa males were enumerated as being employed outside their home area (Ghana Population Census 1960).

\section{b. Changes effected in the Customary Land Tenure System}

The colonial administration's strengthening of the chiefs' authority weakened the position of the teng-nyono in Builsa society. Formerly, chiefs "used to command people not land" (1), but gradually they came to acquire a large measure of control over land as well. Today, the Builsa paramount chief, the Sandemnab, and his elders claim that allodial title to Builsa land is vested in the paramount chief who holds the land in trust for the benefit of the people; the day-to-day administration of land is delegated to the local chiefs on behalf of the paramountcy and to the teng-nyam. (2) Nowadays, if a member of the community wants to acquire a piece of uncultivated land, he has to obtain permission from the local chief; the latter, in turn, has to consult the teng-nyono first before giving his permission. Only after the chief has given his consent and the teng-nyono has performed the necessary rites, is a member of the community concerned allowed to begin cultivating the land in question. In case of allocation of land to strangers, it would, however, seem that local chiefs have to seek authorization from the paramount chief first before consulting the teng-nyono. Members of the community as well as strangers are at present expected to offer a small portion of the produce after harvest to both the chief and the teng-nyono.

c. Superimposition of a "Modern" Land law on the "Neo-

The colonial administration created a dichotomy in the land law in Ghana, whereby all lands in Northern Ghana became vested in 


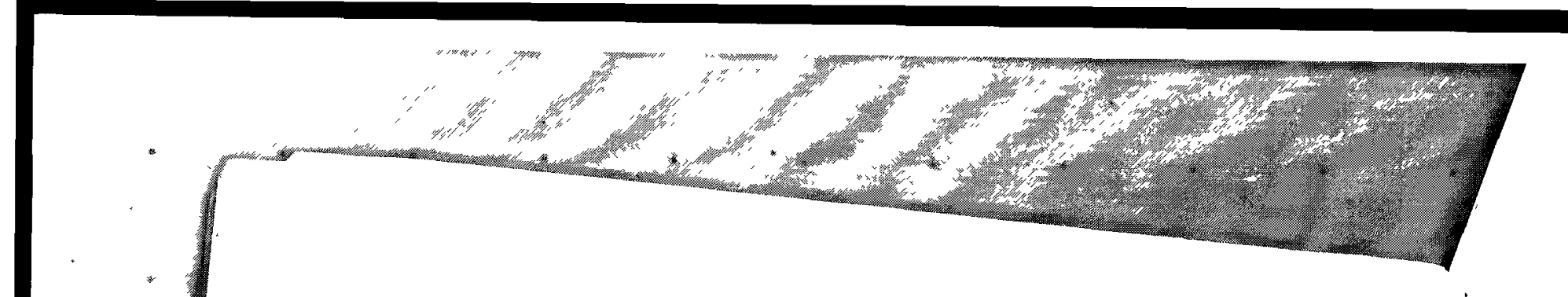

22 JOURNAL OF

1984 ALURALISM

the head of state and lands

chiefs. This difference lands in Southern

and Northern Ghana flowed control over Ghana were held by the failure in the l890s to vest from the land between Southern before tha - where land had "waste" and forest) administration's in Southe introduction of had acquired a comm lands in SouthAborigithern Ghana, of colonial rule - in thercial value even class-bines Rights Protection by a body state. Opposition rich cash-cropanization of intelleciety, which wasn as the the inalienabop producers, inducectuals, bureaucrats in fact a to their the (Kimble 1963). Chiefs and people of Southern

however, met achieve control

Ghana as a labor resuccess as the lands in Northern Ghana, the commen which opposition ed elite excialization of land-use Southern Ghana of those facous reasons of mobilising chief and the existence was centered: control over why the colonial admind people. Ther an educatthe South: lands in Northern administration sougere are vari-

Ghana, after its eart to acquire

alienation of Northern lands to unscrupulous the permanent
to preserve the "customary" land
be respected

"indirected and upheld

indirect rule". (3) upheld under the British stem that had to

Governor Guggisberg's railway route to therg's vision, enunciated

would for commercial agriculturopen up that in the 1920s, a needed enable the colonial are. Control ov part of the couning equitabl the railway project wistration to Northern lands the North and compensation. The without the necessity the land plemented and the building of plans for the opsty of payGhana's role as they were clearly in Souther role as supplier clearly in conflict were never imthe North was no. However, the for the export Northern The fact was never abrogated. special colonial land lawy of never that the special tand tration repealed may be land-law regime for the market which ing interest in curby the colonial North was development ture and other capitalist relations have given rise of a land thereby threar sectors of the of production in to the plier for theatening Northern the Northern Ghanaian in agriculthe Southern Ghanaian export function as labor sup, tanaian export economy. 
In 1927, a Land and Native Rights Ordinance was proposed, declaring all lands in the North "public lands" - without any prior consultation having taken place with the Northern chiefs and people (Der 1975). This Ordinance was vehemently opposed by the Southern Ghanaian educated elite in the Legislative Council as well as by the Ghanaian newspapers. Both this Ghanaian protest and the Colonial Office's dissatisfaction with the Ordinance induced the colonial administration to amend it in 1931 and to recognize Northern lands as being "native lands". However, the "management, control and administration of 'native lands'" was vested in the governor, in trust for the people of Northern Ghana. The 1931 Land and Native Rights Ordinance empowered the Governor to grant rights of occupancy to "Natives and Non-Natives" and to extract a rent in respect of rights of occupancy so granted (Agbosu 1978). The far-reaching effects of this Ordinance were: (i) that chiefs and teng-nyam were excluded from the administration and management of the land in their areas of jurisdiction (though their role was largely maintained in practice); and (ii) that the Lands Department which managed the lands in Northern Ghana could henceforth claim any land in the North for "development purposes" without having to pay any equitable compensation, and/or lease such land -as the Five-Year Development Plan 1975/76-1979/80 has recently emphasized - to "individuals and institutions interested in undertaking large-scale farming". (4)

Following the attainment of independence (1957), the 1931 Land and Native Rights Ordinance was repealed by the State Property and Contracts Act 1960 (C.A.6). However, the new Act not only vested the control of the Northern lands in question in the President of the First Republic but also exhorted him to exercise that control for the "Public Service of the Republic". Two remarks are appropriate here:

- Since Act C.A.6 dealt with state property and contracts, its stated application to lands in Northern Ghana was incongruous and unfortunate. For the Northern lands in question had never been declared state property during the colonial period.

- The wording of Section 1 of the said Act was even more unfortunate as it referred to "any property vested in the crown as trustee for the Public Service of Ghana". However, the Northern land had never been vested in the crown as trustee for the Public Service of Ghana but rather in the Governor as trustee for the chiefs and people.

In 1962, the Parliament of Ghana passed the Administration of Lands Act 1962 (Act 123). In terms of this Act, the President was empowered to declare by Executive Instrument any stool 
lands (5) in Ghana as vested in himself to hold in trust. Although the State Property and Contracts Act 1960 had ostensibly made action in terms of the Administration of Lands Act unnecessary for Northern lands, 1963 nonetheless witnessed the promulgation of Executive Instruments 87 (relating to lands in the Upper Region) and 109 (relating to lands in the Northern Region). The continuing vestment of Northern lands in the head of state after independence must have arisen from the post-colonial state's interest in acquiring Northern lands easily and inexpensively for large-scale, mechanized cash-crop production.

The dichotomy in the land law of Ghana was not resolved by the 1969 Constitution of the Second Republic (Konings 1981a: 15-16). The 1969 Constitution did, however, set out proposals for the creation of a Lands Commission to manage the lands vested in the president. The various responsibilities of this Lands Commission were later defined by the Lands Commission Act of 1971 (Agbosu 1980: 123).

The dichotomy in the land law of Ghana had to face increasing opposition in the 1970s from enlightened Northern chiefs and intellectuals, the products of the extensive educational investment in Northern Ghana during the Nkrumah period (1957-1966). Numerous protests and appeals to the government resulted in December 1977 in the state agreeing in principle to a memorandum drawn up by the Ministry of Lands and Mineral Resources, advocating the repeal of Executive Instruments 87 and 109 of 1963 and the return of the ownership of Northern lands to the traditional owners. In order to ensure a smooth transfer to the traditional owners, the Commissioner for Lands and Mineral Resources decided to set up the R.L. Alhassan Committee "to determine the ownership of lands and the position of tenants in the Northern and Upper Regions". (6) The Alhassan Committee Report was, however, never acted upon by the then military government, the SMC. The 1979 Constitution of the Third Republic finally revested Northern lands in the traditional owners. (7)

The Post-Colonial State's Promotion of Capitalist Rice Farming in Northern Ghana

The post-colonial state in Ghana has been increasingly concerned with the country's recurring food shortages, high food prices, and rising food imports (Konings 1981 a and $b$ ). The record of rice production clearly demonstrates the growing gap between local production and demand: about 50-70\% of Ghana's rice requirements had to be imported between 1960 and 1970, thereby considerably depleting Ghana's foreign exchange reserves (Okoso-Amaa 1975:73). All post-colonial governments have con- 
sidered the peasantry - largely producing for its own subsistence with "archaic" production tools - as incapable of meeting the increased demand for food. Consequently they have mostly relied on large-scale mechanized farming.

Northern Ghana - an area starved of development funds and transformed under colonialism into a labor reserve for the South Ghanaian export economy - features prominently in the postcolonial state's attempts to promote large-scale, mechanized farming. Northern Ghana, as a colonial report noted in the early fifties, "has three major assets, none of which have yet been developed: large areas of unused land, rivers and labor" (8), which make it an extremely suitable area for large-scale, mechanized farming. Vast tracts of uncultivated land were not only available in the sparsely populated areas of Northern Ghana, but also in the numerous river valleys in the more densely populated regions of the North: the seasonally-flooded, heavy clay river valley lands (fadama) are not arable with traditional farming methods and are often infested with river blindness (Patterson 1978). The continuing vestment of Northern lands in the state enabled post-colonial governments to claim such lands easily and cheaply. Moreover, the North was considered to possess a large reservoir of cheap, underemployed labor. The introduction of large-scale, mechanized farming would then have the additional advantage of halting, or at least slowing down, the southward flow of unskilled labor - which can no longer be absorbed by the slowly-expanding, capital-intensive industrial sector - and of creating local employment opportunities in the vital agricultural sector.

The failure of the large-scale, mechanized state farms and co-operatives established during the Nkrumah period (1957-1966) to raise food production (Miracle and Seidman 1968a and b; Due 1971), combined with the ideological commitment of subsequent governments to the promotion of private enterprise, has laid the foundation for capitalist (rice) farming in Northern Ghana (Shepherd 1979; Konings 1981a). A conscious effort was made by the NLC military government (1966-1969), but particularly by the subsequent civilian government (1969-1972), to create a class of capitalist farmers among the urban-based "better-educated and better paid" petty-bourgeois fractions in society (civil servants and businessmen). The provision of foreign exchange to import machinery and inputs, of highly subsidized inputs and agricultural services (subsidies on fertilizer rose from $50 \%$ of cost in 1970 to $81 \frac{\circ}{0}$ in 1976, while subsidies on agricultural services increased from $50 \%$ to $74 \%$ ), of improved extension services geared to "progressive farmers", and of a minimum of infrastructure, and the establishment of various government rice mills in Northern Ghana (ensuring a - steadily rising- guaranteed floor price 
for paddy), have proved to be important incentives to investment in capitalist rice farming. The expansion of capitalist rice farming has depended above all else on bank loans. Investment in rice production was initiated by the state-owned Agricultural Development Bank (ADB) in 1968, and soon followed by the foreign-owned commercial banks and the part state, part privately-owned National Investment Bank (NIB). By the midseventies there had arisen in the Northern towns an embryonic class of capitalist rice farmers that was dependent on: a) the state, for highly-subsidized inputs and agricultural services; b) the banks, for low-interest loans; and c) the local peasant communities, for easy access to cheap (uncultivated) land and (casual) labor.

Capitalist rice farming started in the Northern Region, in particular the Tamale agricultural district, where there are numerous uncultivated river valley lands. In 1976 there were, according to Shepherd (1981: 174), some 800 bank-financed capitalist rice farmers in the Northern Region. Capitalist rice farming started later in the Upper Region where there is only one large river valley suitable for large-scale, mechanized rice production, namely the Gbedembilisi Valley in the Builsa Traditional Area. Capitalist Rice Farming and Peasant Communities in the
Gbedembilisi Valley

The rice potential of the Gbedembilisi Valley (including the flood plains of two rivers, the Sisili and Kulpawn, probably the most fertile rice valley in the whole of Northern Ghana) was "discovered" by four stranger farmers of Sisala origin in 1973 (Konings 1981a). Their request for land to the regent of Gbedembilisi (the chief having just recently died) was well received, as the valley lands could not be cultivated by local peasants with traditional farm implements and were only used for grazing, fishing and hunting purposes. Moreover, these lands were infested with river blindness. The Sisala group started farming in 1974 and soon their pioneering efforts were bearing fruit. Their success soon attracted a number of "followers" to Gbedembilisi and Wiasi, the two "rice villages" on the Upper Region side of the valley, most of whom had obtained bank loans from the $A D B$ : while sixty rice farmers were in receipt of $A D B$ loans in 1975, their number had risen to 123 farmers in 1978, in all cultivating 22,227 acres of land. Some of these farmers had been granted loans from the commercial banks as well.

The first phase, 1974-1976, proved to be the most promising. Particularly the 1976 bumper harvest attracted a large number of newcomers (including many civil servants) to the Gbedembilisi 


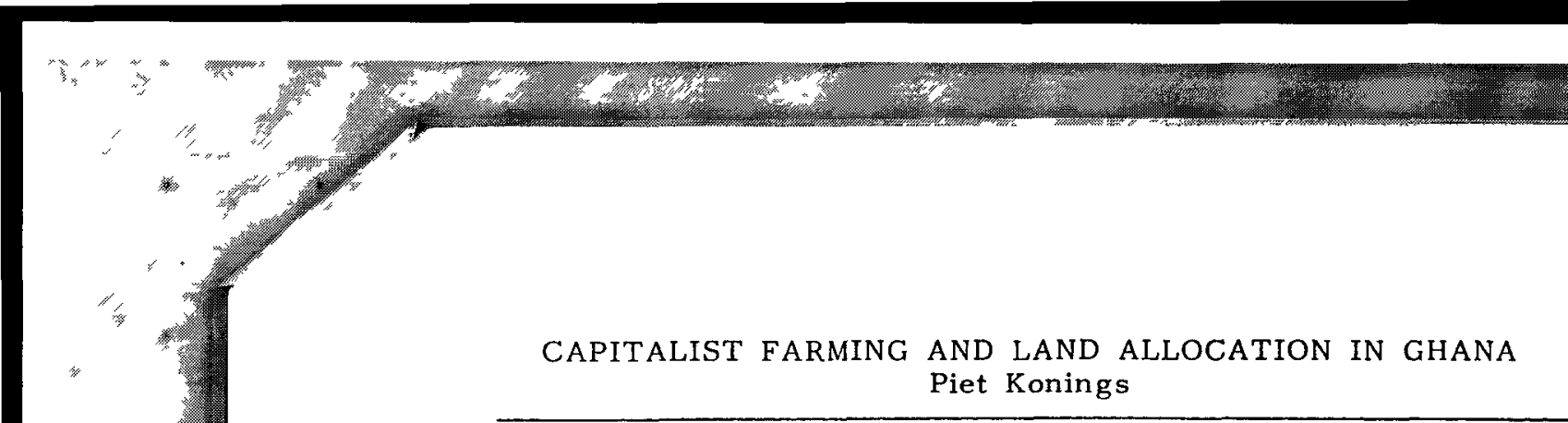

Valley. However, from 1977 onwards, various calamities (droughts and outbreaks of fire) and serious shortages of inputs and machinery reduced the number of rice farmers (see table 1).

Table 1: Number of Rice Farmers at Wiasi and Gbedembilisi, 1974-1979

\begin{tabular}{|lc|}
\hline year & number \\
\hline 1974 & 4 \\
1975 & 73 \\
1976 & 153 \\
1977 & 210 \\
1978 & 135 \\
1979 & 60 \\
\hline
\end{tabular}

Source: Konings 1981a: 60.

Most rice farmers who rushed to the valley to join the rice bonanza were stranger farmers. In 1977, only twenty of the rice farmers were Southerners, most of whom were relatively highly educated civil servants, professionals, managers and military officers stationed in the administrative/urban centers in the Upper Region. Only a handful of the remaining 190 Northerners were Builsa: their number rose from 8 in 1975 to 14 in 1976 and reached 23 in 1977. Among the Builsa there were only 5 farmers from the two rice villages, including the two local chiefs. Most of the Builsa were to be found among the small and least capitalized farmers. Most of the other Northerners were members of neighboring ethnic groups (Sisala, Mamprusi, Kasena and Frafra), but there were also quite a number of Wala among them. Some of these Northern farmers (especially the full-time farmers) stayed in the rice villages or other Builsa towns during the farming season; others were absentee farmers who visited their farm(s) more or less regularly. Only very few stranger farmers stayed (semi)-permanently in the Builsa towns, especially those who had been - or still were - engaged in the cattle trade in the Builsa area, the center of the cattle trade in the north-east of Ghana (Hill 1970). The variety of ethnic groups did not prevent the establishment of inter-ethnic ties among capitalist rice farmers for purposes of mutual help and defence of their interests. The under-representation and generally weak position of Builsa among the capitalist rice farmers, however, constituted a potentially explosive situation. In the past, strangers wishing to settle down on Builsa land were welcomed and given land freely (at the time land was not yet a scarce commodity with commercial value; 
and only a tiny portion of Builsa land could be worked with traditional farming implements). However, the large-scale "alienation" of Builsa lands to mechanized stranger farmers was more likely to arouse Builsa ethnic feelings, the more so as most of the farmers concerned did not intend to settle down on Builsa land but were rather interested in "syphoning off" to their home area the profits to be made there.

Capitalist rice farmers were, moreover, differentiated not only along ethnic lines but also along occupational lines, a fact which in turn gave rise to unequal distribution of socio-political power and unequal access to scarce economic resources among capitalist rice farmers and to intra-class conflicts (see table 2).

Table 2: Social Composition of Wiasi and Gbedembilisi Rice Farmers in 1977

\begin{tabular}{|lrc|}
\hline social position & number & $\frac{\circ}{\delta}$ \\
\hline 1. Military officers (including the & 15 & 7 \\
2. retired and prison officers & 4 & 2 \\
3. Colice and pris servants & 38 & 18 \\
4. Managers (banks, state and private & 9 & 4.5 \\
corporations) & 6 & 3 \\
5. Professionals (doctors, lawyers etc.) & 6 & 3 \\
6. Companies (Northern Engineering Co.etc.) & 7 & 3.5 \\
7. Chiefs & 3 & 1.5 \\
8. Ex-CPP politicians & 15 & 7 \\
9. Transport owners/drivers/mechanics etc. & 7 & 3.5 \\
10. Contractors & 47 & 22.5 \\
11. Businessmen/traders & 3 & 1.5 \\
12. Institutions/organizations & 2 & 1 \\
13. Co-operatives (of stranger "peasants") & 48 & 23 \\
14. (Mainly) farmers & 210 & $100.0 \frac{8}{8}$ \\
\hline total & & \\
\hline
\end{tabular}

Source: Konings 1981a: 63 .

Within the class of capitalist rice farmers, we may distinguish the following fractions:

(1) The military/police officers and civil servants, constituting the most powerful fraction within the class of capitalist rice farmers. Hutchful's thesis (1979: 36-55) to the effect that the NRC/SMC military regimes (1972-1979), based on an alliance between the military and the bureaucracy, not only 


\section{CAPITALIST FARMING AND LAND ALLOCATION IN GHANA Piet Konings}

promoted capitalist enterprise but also used its political power to establish an economic base for its political power, is borne out by this group's marked representation among capitalist rice farmers in the Gbedembilisi Valley. A good number of the absentee military rice farmers were members of the military regime itself or its close associates, such as (retired) Regional Commissioners. The military and civil servants (but also other fractions like managers and professionals) were appropriating a large share of the state's and banks' allocation of funds and resources to capitalist rice farming in Northern Ghana. They belong to the most highly capitalized group of farmers in the valley.

(2) Ex-CPP politicians. Both Ladouceur (1979: 214-215) and Shepherd (1979: 71) refer to the important role ex-CPP politicians, unable to return to politics after the 1966 coup, played in the establishment of capitalist rice farming in the Northern Region. Their role in capitalist rice farming in the Gbedembilisi Valley was much more modest. Only three important national and regional CPP politicians were farming in the valley; they cultivated only a relatively small acreage.

(3) Chiefs. In the valley, the "traditional" wielders of power, the chiefs, were to be found farming alongside the "modern" wielders and ex-wielders of power. The Builsa paramount chief, the Sandemnab, and two Kasena chiefs, the Navropio and the Chianapio, acquired vast acreages of land in the valley from local chiefs; they belonged to the group of most highly capitalized farmers in the valley. Although the two local (Gbedembilisi and Wiasi) chiefs belonged to the group of least capitalized farmers, they were nevertheless able to benefit in many ways from capitalist rice farming in the valley (see below).

(4) Entrepreneurs/traders/businessmen. Some rice farmers were successful entrepreneurs like transport owners and contractors. A large number of them, such as the Muslim Wala (often engaged in cattle trade and other forms of trade) and well-off Southern businessmen in Northern towns, had accumulated "merchant capital" before embarking on rice farming. Most of them did not intend to leave their business or trade altogether. Rice farming provides them with a (potentially lucrative) opportunity to spread risks, while it also makes possible a constant re-cycling of capital from rice farming into business/enterprise and vice versa.

(5) Full-time farmers. Although some of these farmers were highly capitalized, like the four pioneering Sisala, most of them had experienced difficulties in acquiring loans from the 


\section{JOURNAL OF LEGAL PLURALISM}

1984

banks and agricultural inputs and services from the Ministry of Agriculture. They resented the flow of scarce resources to absentee farmers, a fact which made them - the "real" farmers - often dependent on the more highly capitalized absentee farmers for agricultural services. The establishment of patron-client relationships was, moreover, of ten facilitated (and made more easily acceptable) by ties of ethnicity and religion (particularly Islam).

Capitalist rice farmers were able to benefit from local peasant communities in two ways:

(1) Acquisition of large acreages of cheap valley land.

The acreage acquired generally varied from about 50 to over 1,000 acres, largely determined by the degree of the individual farmers' capitalization. The rice farmers' acquisition of large acreages of land has had some adverse consequences for local peasant communities:

- Though the rice farmers' acquisition of large tracts of land has not (yet) resulted in the expropriation of peasants' land (as the valley lands were not cultivated by peasants), it blocked the peasants' access to grazing, hunting and fishing lands. At the same time, such land appropriation has forestalled the possible entry of peasants into large-scale rice farming by either joining the ranks of capitalist rice farmers (a possibility open only to the very few who have been able to accumulate capital from cattle trade) or by forming co-operative farms.

- Many rice farmers - being stimulated by access to cheap land and high state subsidies for agricultural services - practise an ecologically-destructive, large-scale shifting cultivation: they cultivate only a part of the land acreage acquired, with little regard to soil fertility maintenance (no proper land preparation, fertilizing, and weeding, which require considerable investment) and shift to another part of their farm (or to other farms acquired in the rice villages) when soil fertlity is depleted (Bennett and Schork 1979). Thus local peasant communities - at least initially ignorant of this ecologically-destructive farming method - had large tracts of land rendered useless over a short period of time.

While local peasant communities suffered from the allocation of large tracts of valley lands to capitalist rice farmers, the real beneficiaries were the local chiefs. Local chiefs behaved like landlords through their "uncustomary" monopolization of land allocation in the valley and their virtual rejection of the state

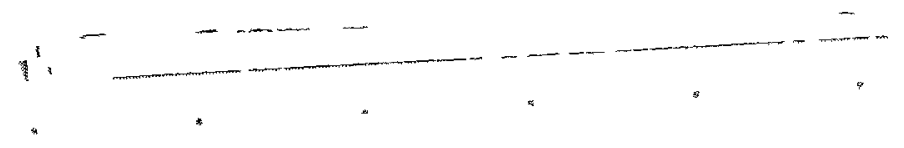




\section{CAPITALIST FARMING AND LAND ALLOCATION IN GHANA Piet Konings}

control over Northern lands established during the colonial period:

a) Local chiefs vehemently opposed any rice farmer who tried to acquire a lease from the Lands Department, which charged an annual land rent of $\mathbb{Q} 0,50$ an acre, to be distributed as follows: $10 \%$ to the collecting body, and $45 \%$ each to the Local Council and Traditional Council respectively. Some farmers preferred a lease from the Lands Department, as such a lease provided them with a more secure title to land than a "customary" lease which could in principle always be revoked. The following are some of the reasons for the opposition of local chiefs to leases issued by the Lands Department:

- their increasing rejection of the established land law, whereby Northern Lands are vested in the head of state, and of the Lands Department's management of such lands. A Lands Department lease was considered as an infraction of the chief's power to administer lands under his jurisdiction, particularly when the prospective farmer did not first approach the chief for a "note of introduction".

- their fear that such leases might be interpreted as "sale of land" contrary to the customary land tenure system.

- the absence of a "token of respect" (customary gifts) for the land-granting authority and of a share in the land rent paid to the Lands Department (which rent accrued in part to the Traditional Council rather than to the local chiefs).

Most rice farmers, fearing reprisals from the local chiefs, never dared to apply for a lease from the Lands Department so as to make their "customary" lease more secure. By 1977, only four applications (including one from the Navropio and one from the pioneering Sisala farmers) had been lodged with the Lands Department at Bolgatanga; and only one of these applicants, Major Achaab, a Builsa, was granted a lease by the Lands Department.

b) Local chiefs soon became aware of the value of the Gbedembilisi Valley lands, a situation which led to all kinds of abuses of the customary land tenure system. These chiefs began to look upon the valley lands as their personal property upon which nobody - neither "traditional" nor "modern" authorities should intrude. Consent of the paramount chief was no longer sought before leasing lands to stranger farmers, despite warnings. Similarly, the teng-nyam were no longer being consulted; in their turn, they refused to perform the necessary rites when land was allocated by local chiefs to stranger farmers. Local chiefs demanded more and more gifts and a higher monetary amount - though this was still rather low compared with the "drinks" demanded by chiefs in Southern Ghana (Konings 1982) 
- before leasing valley lands to farmers, and also began to raise what could only be described as a sort of "ground rent". Thus, in 1979, the Wiasi chief sent out a letter to all rice farmers in his village, requesting ten bags of paddy after harvest. The teng-nyam (and community members) never received their proper share of the gifts of appreciation donated by the rice farmers. In addition to receiving "customary" gifts from rice farmers, local chiefs were assisted by the former in setting up rice farms of their own. Rice farmers, moreover, usually cultivated the rice farms of the local chiefs.

\section{(2) Supply of relatively cheap, casual labor.}

The emergence of capitalist rice farming has created a dual labor market in the Gbedembilisi Valley (Konings 198la). Part of the workforce employed is permanent - skilled and unskilled - labor, usually recruited from the rice farmer's home area and closely connected with the employers: the large majority of permanent workers are either kinsmen or trusted and experienced men who are often more or less incorporated into the employer's kin group. The remainder of the workforce employed is casual labor, usually recruited among local peasants in the rice villages. Capitalist rice farming has increased the flow of labor out of peasant agriculture but partly re-directed it from the Southern export economy to the local rice fields. Most casual workers are young men and women who used to migrate to the South but now often prefer to stay in the valley because of the employment opportunities created in the rice fields and the free accommodation and food enjoyed in the family house. Widows and divorcees often form part of the casual labor force as well. These casual workers are often (still) denied access to land except for a small plot, so they tend to work more or less regularly in the rice fields (particularly at times when themr labor power is not badly needed on the family farm) since such work enables them to secure, or enlarge, an income of their own. Most older married men and women, and in particular household heads, hardly look for employment in the rice fields; their responsibility is to look after the famlly's upkeep through the cultivation of the family's food farms. Household heads often attempt to start, or increase, potentially lucrative rice production; they are, however, usually dependent on capitalist rice farmers for the provision of mechanized services and fertilizer. The shortage of (casual) labor in the valley has had an upward effect on wages: while wages of casual workers in the private agricultural sector in the North used to be below the minimum wage (Rourke and Sakyi-Gyinae 1972), the existing labor shortage in the valley has raised wages at least to the dally minimum wage of $\mathbb{Q} 4$ in 1979 and mostly a little above it ( 45 was the most common wage in 1979). Casual workers appreciate, on the one hand, the employment oppor- 


\section{CAPITALIST FARMING AND LAND ALLOCATION IN GHANA Piet Konings}

tunities created by capitalist rice farming, which provides them with an income that compares favorably with that of unskilled urban workers. On the other hand, they often display quite ambivalent attitudes towards capitalist rice farming in the valley: they appear to share at least some of the elders' grievances.

The elders increasingly resent the allocation of vast tracts of valley lands to mainly stranger farmers since this blocks their own entry into large-scale farming through the establishment of co-operative farms in the valley. They believe that the local communities' supply of relatively cheap land and labor to rice farmers has given rise to the latters' huge capital accumulation with minimal local benefits. The rice produced in the valley is largely transported to the Southern urban markets or across the Ghanaian borders, without (substantially) adding to the local peasants' precarious food supplies. And the daily wage of $\mathbb{C}$, while comparing favorably with the wage rates of unskilled urban workers, is not only very low in relation to the cost of living but also easily spent. Moreover, stranger farmers "syphon of $f^{\prime \prime}$ to their home towns the "huge" profits made on the valley lands, without in any way making a contribution to local "development". Stranger farmers are regarded not only as exploiters of the local communities' lands and labor but also as their actual "rulers", following their "buying over" of the local chiefs. They are seen as having created disunity between the local chiefs on the one side, and the paramount chief, the teng-nyam and members of the community, on the other.

The emerging class conflict has not as yet given rise to any form of organized opposition, mainly for two reasons:

- First of all, the peasant communities' leaders, the local chiefs, have been "co-opted" into the class of capitalist rice farmers and therefore protect the rice farmers as long as the latter adhere to the terms of the land leases granted.

- Secondly, local peasants depend on the rice farmers for the supply of agricultural inputs and services (some elders) or employment (particularly young men and women).

The conflict between the local peasants and the rice farmers, is, however, discernible in informal, largely individualistic and negative actions, including the "harvesting" of rice in the fields and, occasionally, the burning of rice fields (Goody 1980). While local peasants were unable to establish any form of organized opposition against the rice farmers, their grievances were aired and their interests defended by the Builsa Traditional Council (BTC) and the Builsa Youth Association (BYA), an organization of educated Builsa, during the so-called Gbedembilisi Valley Dis-
pute. 


\section{The Gbedembilisi Valley Dispute}

The so-called Gbedembilisi Valley Dispute arose from a land dispute between the four pioneering Sisala farmers and the Chief's House of Gbedembilisi. However, this local dispute soon developed into a wider conflict between the Builsa (native) state, on the one side, and the national state and stranger farmers, on the other, over the control of Builsa land and the regulation and taxation of capitalist rice farming in the valley. Though it initially appeared as though the BTC, supported and "guided" by the BYA, was successful in its defence of Builsa interests against the state and the rice farmers, its victory proved ultimately to be a Pyrrhic one.

The Sisala farmers, as we have seen above, were welcomed by the Gbedembilisi regent in 1973 and given a "customary" land lease, with no size and duration specified (the consent of the paramount chief, the Sandemnab, was, however, not sought). When newcomers entered the valley in 1975, the Sisala farmers requested, and obtained, the regent's permission to demarcate their land. Thus a vast area of about 2 to 3 square miles of the most fertile land in the valley became demarcated. However, the regent allowed four new farmers to farm on as yet uncultivated land within the recently demarcated area (for a handsome reward!), thus blocking the Sisala farmers' future expansion possibilities. When the Sisala started to quarrel with the four newcomers and lodged a protest with the regent, they were told to stop farming in the valley because of their "greediness" (not allowing other farmers access to as yet uncultivated land) and that the land (according to the regent's new version) had only be given to them for a two-year period. Furthermore, and this point was later conceded by the complainants, they had contravened custom (punishable by eviction) by subletting land to Sisala "brothers" without the regent's knowledge and consent.

The Sisala farmers, in turn, did not seek redress, as custom demanded, from the Paramount Chief, the Sandemnab, the custodian of Builsa lands and arbitrator in any land disputes - they suspected him of partiality to the Gbedembilisi Chief's House but directly approached the Regional Commissioner, Col. Acquaye-Nortey. After having received a report on the dispute, drawn up by the Builsa District Chief Executive, the RC ruled that the Sisala had acquired the land with the regent's consent and in accordance with customary law; he rejected the Gbedembilisi regent's quit order to the Sisala farmers as being detrimental to the government's policy of achieving selfsufficiency in food production (the Builsa, however, alleged that the Sisala had "bought" the RC over by offering him help in the establishment of a rice farm in the valley). 


\section{CAPITALIST FARMING AND LAND ALLOCATION IN GHANA}

Piet Konings

The dispute was still unresolved when Col. Acquaye-Nortey was transferred and replaced by Major Ofori-Akuomoah who took up the matter after the newly-elected Gbedembilisi chief again began to allocate land within the demarcated area. At the time, the Sandemnab had appointed a committee to investigate the matter. The new RC, however, did not wait for the outcome of this arbitration effort by the custodian of Builsa lands, but appealed to the Upper Regional House of Chiefs for a settlement of the dispute. A two-man committee - comprising the president and expresident of the Upper Regional House of Chiefs, the WellembeleKuoro (a Sisala himself!) and the Chianapio, both capitalist stranger farmers in the Gbedembilisi Valley - was formed to "assist" the Sandemnab in finding a suitable solution to the land dispute. The appointment of the Wellembele-Kuoro Committee aroused Builsa ethnic feelings. The BTC regarded the committee as constituting an outside (state) interference in matters which ought to be handled by its president, the Sandemnab, and as being partial to the claims of stranger farmers and therefore inimical to Builsa interests. (9)

The internal conflict within the BTC between the Sandemnab and the Gbedembilisi chief - who had "recklessly" allocated land to stranger farmers without seeking prior permission from the paramount chief as custom demanded - disappeared to the background when Builsa chiefs (BTC) and "intellectuals" (BYA) rallied to defend Builsa interests against "outside" interests (though the Gbedembilisi chief was reproached by the Sandemnab during a BTC meeting and had to apologize). The dispute now more and more assumed the character of a conflict between the BTC, supported by the BYA, on the one hand, and the state and stranger farmers, on the other, about control over Builsa Lands and the "regulation" (and taxation) of rice farming in the valley. Though the BTC, "guided" by the BYA, was not opposed to state-supported capitalist rice farming in the valley, it wished to guarantee and defend Builsa interests against those of the state and stranger farmers by the following means:

a) Claiming control over Builsa land: The BTC maintained, in the wake of increasing opposition by Northern chiefs and intellectuals to the established land law vesting Northern lands in the head of state, that Builsa lands were vested in its president, the Sandemnab, and disputed state interference in Builsa land matters.

b) Attempting to regulate and streamline the system of land allocation with regard to capitalist rice farming in the valley: The introduction of capitalist rice farming in the Gbedembilisi Valley had necessitated a rationalization and centralization of the traditional system of land allocation so as to forestall large-scale "alienation" of Builsa lands, to overcome the un- 
equal distribution of lands in the valley and to prevent breaches of custom. For that reason, the BYA, after having investigated the causes of the dispute, proposed to the BTC the setting up of a Land Allocation Committee which would issue rules and regulations about land leases to capitalist rice farmers and with which all agreements about land leases would have to be re-negotiated.

c) Securing a larger Builsa share in the valley lands by allocating larger tracts of valley lands to Builsa farmers than to stranger farmers and by organizing co-operatives among "our poor people" for large-scale farming and by increasing the local benefits from the farming of Builsa lands (by taxing capitalist rice farmers for the benefit of the whole Builsa area, which is one of the least developed areas in the North) before stranger farmers, practising an ecologically-destructive, large-scale shifting cultivation, have left the area. (10)

The climax of the conflict was reached when the RC accepted the main recommendations of the Wellembele-Kuoro Committee's Report which stated (i) that the Sisala farmers should continue to cultivate land in the disputed area; and (ii) that other farmers should be evicted but be given compensation for the plots ploughed in the disputed area. (11) The Sandemnab strongly opposed the conclusions of the report and ruled that "all farmers in the area should continue to farm and prepare themselves to accept and to abide by the decisions of the BTC which will meet soon". (12) However, the RC sent Major Addah, Border Guards Commander, and the Regional Agricultural Officer, to Gbedembilisi with letters containing quit orders to the four farmers who had been allowed into the disputed area by the Gbedembilisi Chief's House. Remarkable in this regard was that a more recent "invader" of the disputed area, Col. Felli, a prominent government member, was not similarly ordered to leave by the RC.

Meanwhile the Gbedembilisi chief forbade a Ministry of Agriculture survey team, instructed by the RC to survey the disputed area, to carry out its work. Reportedly, the chief told the team that since the land in question was Builsa land he would only allow them to undertake the survey on instructions from the Sandemnab, the custodian of Builsa lands. (13) Enraged by the chief's act of "sabotage" and his continuous refusal to allow the Sisala to farm in the disputed area, the RC went down personally to Gbedembilisi - thereby once again bypassing the Sandemnab - to threaten the chief. He was, however, rebuffed by the chief and constantly referred to the Sandemnab. The RC took offense at the chief's behavior and made it clear that if the Sisala were not allowed to continue farming on Builsa lands, ev- 


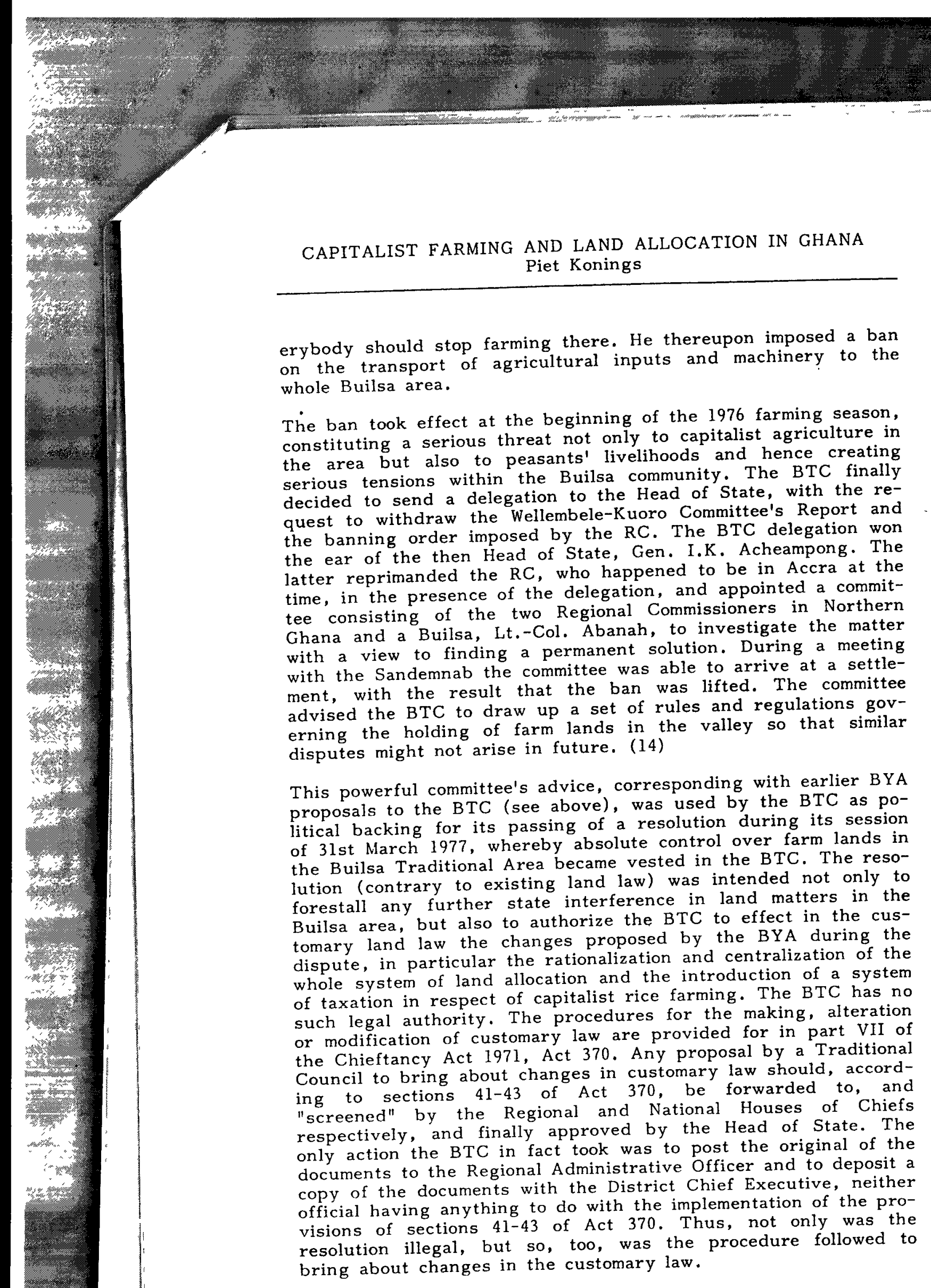

erybody should stop farming there. He thereupon imposed a ban The BTC finally 列 withdraw the Wellembele-Kuoro Committee's Report and the banning order imposed by the RC. The BTC delegation won in was able to arrive at a settlethe committee was able to arrive at a settleBTC to draw up a set of rules and regulations govBTC to effect in the cust and centralization of the dispute, in particular the rationalization and centralization of the of taxation in respect of capitalist rice farming. The BTC has no such legal authority. The procedure ication of customary law are provided for Act 370 . Any proposal by a Traditional 41-43 of Act 370 , be forwarded to, and "screened" by the Regional and National Houses of Chiefs respectively, and finally approved by the Head of State. The of the documents with the District Chief Executive, neither visions $41-43$ of Act 370. Thus, not only was the lllegal, but so, too, was the procedure followed to bring about changes in the customary law. 


\section{JOURNAL OF LEGAL PLURALISM 1984}

The centralization of the land allocation system was achieved by the formation of a Land Allocation Committee, under the chairmanship of the Sandemnab, which was to be the sole authority for the allocation of land in the Builsa Traditional Area. The BTC Land Allocation Committee was composed of 2 BTC chiefs, 1 chief from the village in question, 1 teng-nyono of the same village, and 2 members of the BYA. Its membership therefore comprised both those who customarily dealt with land matters in the Builsa Traditional Area, viz, the chiefs and teng-nyam, and those who became involved in land matters after the introduction of capitalist rice farming with its attendent conflicts, namely, the educated Builsa (organized in the BYA). The latter group was "co-opted" particularly for its ability to put down in legallybinding documents the unwritten code of customary land tenure and the changes brought about in it. Such documentation was more and more seen to be required to protect and defend the local peasant communities' rights of ownership. Though the wording of the resolution and other related documents might suggest that the BTC Land Allocation Committee was to handle land allocation in the whole Builsa area, its responsibility did not in fact extend beyond the allocation of land to rice farmers in the Gbedembilisi Valley.

The BTC Land Allocation Committee began to issue rules and regulations with regard to capitalist rice farming. It took pains to see to it that such rules and regulations were written down and applied to all rice farmers without exception so as to obviate any possible abuse. Discriminatory measures against stranger farmers (proposed in earlier BYA documents), such as allocating larger acreages of land to Builsa than to non-Builsa farmers, were carefully avoided, as they might give rise to new conflicts within the Gbedembilisi Valley. The BTC Land Allocation Committee issued the following main rules and regulations:

a) with regard to land allocation: All rice farmers should re-apply for farm lands in the valley; specific limits were set to the acreage of a lease (a non-mechanized farmer would be able to acquire not more than 100 acres, a mechanized farmer not more than 100-150 acres, a company/group not more than 200-500 acres) and to the duration of a lease (a term of 5 years subject to abrogation or renewal at the option of the BTC Land Allocation Committee). This rule allowed for more evenly distributed opportunities for capital accumulation within the class of capitalist rice farmers in the valley.

b) with regard to taxation: All rice farmers should contribute one bag of paddy per acre. The tax should be divided as follows: one-third to be given to the village chief to share between the teng-nyono of the area and himself, two-third to 
go to the BTC for development projects, scholarships, and to meet the BTC commitments. (15)

Considering the nature of the rules and regulations issued by the BTC Land Allocation Committee we may agree with Shepherd (1979: 206) who has predicted that,

the centralization of the allocation of scarce resources, especially land, and the centralization and rationalization of the collection and disposal of what amounted to a ground rent ... would increase the economic power of the traditional council in a fashion unprecedented in Northern Ghana.

Not unexpectedly, the resolution and the new rules and regulations governing capitalist rice farming gave rise to conflicts with the state, the local chiefs of the rice villages and the capitalist rice farmers.

The state appointed an Administrative Committee on Allocation of Farm Lands in Builsa District on 29 June 1977, to ascertain, among other things, the real objectives and legality of the resolution passed by the BTC and the full implications of the contemplated action in respect of rice farming. While pointing out the illegality of the resolution in question, the committee nevertheless concluded that "having regard to the real objectives or the intentions of the BTC we found the idea of making rules along the lines of the resolution praiseworthy". (16) However, it recommended that in trying to lay down such rules the BTC would be well advised to proceed in accordance with sections 41-43 of Act 370. It furthermore wished to make some amendments to the rules and regulations issued by the BTC Land Allocation Committee, amendments geared at making the rules more conducive to the development and expansion of capitalist rice farming in the Gbedembilisi Valley. For example: there was insufficient security of tenure; the limits set on the acreage to be leased might obstruct the capacity to expand of the more highly capitalized farmers; the length of the leases should be extended so as to enable farmers to pay off the loans and make enough profit; and finally, the tax was judged as being too high. This report was never published or acted upon by the state.

The formation of the BTC Land Allocation Committee once again brought into the open the conflict between the BTC and local chiefs of the rice villages (in particular the Gbedembilisi chief), a confluct that had remained in the background during the whole dispute. The local chiefs opposed the BTC Land Allocation Committee as an instance of "outside" interference in the matter of land allocations in their "kingdoms". They feared a loss of revenue as the BTC Land Allocation Committee would henceforth han- 
dle the profitable allocation of lands in the valley. They also disliked the new system of taxation which "syphoned off" the largest proportion of the taxes to the BTC. The Land Allocation Committee and the new rules and regulations were made into a farce by the local chiefs' opposition, the committee's failure to devise an effective scheme of tax collection, and its hesitation after issuing the new rules and regulations - the committee wished to await government response (which never materialized) to the Administrative Committee's Report on Allocation of Farm Lands in Builsa District before actually imposing the new rules and regulations and challenging the local chiefs. The great losers in all this were the local peasants. While the BTC and BYA had planned to make "room" for peasant participation in large-scale rice farming in the valley, the Land Allocation Committee's failure to implement the new rules and its plans, coupled with the local chiefs' interest in the maintenance of the status quo, prevented the organization of co-operatives by peasants.

Capitalist rice farmers, who initially appeared to be the losers in the dispute, came out victorious in the end. The new rules and regulations were never in fact imposed. The capitalist rice farmers then directed their action against the "high" rate of taxation which ultimately resulted in the reduction of the tax from 1 bag per acre to $\mathbb{Q} 0,50 \mathrm{a}$ bag. The Land Allocation Committee's failure to devise an effective system of tax collection, moreover, enabled the capitalist rice farmers to evade payment of taxes on a large scale.

\section{Conclusion}

This study has tried to demonstrate that the introduction of capitalist rice farming in peasant communities in North Ghana has created serious tensions and conflicts about land and land allocation.

The overall picture portrayed by accounts of the customary land tenure systems in Northern Ghana is that no economic value as such was attached to land. Land was abundant, demand for it was negligible, and it thus had no market value. Hence claims of right to or over it did not feature prominently in the customary land tenure systems. This was, according to Agbosu (1980: 111112 ), also one of the main reasons that the colonial administration did not experience any opposition from traditional authorities to the vestment of Northern lands in the state - in contrast to Southern Ghana where land had already acquired a commercial value during the pre-colonial period. Though the 1931 Land and Native Rights Ordinance granted ultimate control over Northern lands to the governor, hardly any tensions and conflicts about 
land and land allocation arose during the colonial period for the following main reasons: (i) the administration of Northern Ghana as a labor reserve prevented the commercialization of Northern lands (Konings 1983); (ii) very little land was claimed by the colonial administration for development purposes (mainly land in towns for the purpose of establishing schools and administrative buildings); and (iii) the "traditional" authorities were in practice allowed to continue allocating agricultural land (consequently, a number of Northern chiefs did not know that they had no legal rights to allocate land).

The transformation of the North from a labor reserve into a "granary" for the Southern economy after the attainment of independence has given rise to the increasing commercialization of Northern land (Konings 1983). Both the power and profit to be gained from control over valuable land (amply illustrated by the role of the chiefs in Southern Ghana's cocoa regions) and the post-colonial state's actual expropriation of Northern lands for large-scale, mechanized farming without any form of consultation and compensation of local chiefs, have caused a growing resentment among Northern chiefs against state control over Northern lands. Supported by the expanding group of educated commoners they started to protest against what they considered a discriminatory and unfair land law vesting Northern lands - in contrast to Southern lands - in the state. The direct effects of this protest have been that the Lands Department has become more careful during the seventies in issuing land leases to potential farmers and that the 1979 constitution finally restored Northern lands to the traditional owners.

State promotion of capitalist rice farming has led to a scramble for land in the Gbedembilisi Valley, mainly by stranger farmers. Neither the "modern" nor the "traditional" land law has proved to be capable of regulating land allocation to rice farmers. Local chiefs who soon became aware of the economic value of the river valley lands, have not only constantly refused to sanction Lands Department leases, but have also started to monopolize land allocation to stranger farmers in clear defiance of the customary land law. They have been rewarded in various ways for this allocation exercise and have been co-opted into the class of capitalist rice farmers. Their allocation of river valley lands has given rise to an unequal distribution of lands among capitalist rice farmers, blocking local peasants' access to land in the valley for mechanized rice farming, and has brought only minimal benefits to local peasant communities and the whole Builsa area. These were the sources of conflict which ultimately lay at the root of the Gbedembilisi Valley Dispute. 
The Gbedembilisi Valley Dispute prompted the BTC not only to reject the "modern" land law completely in order to forestall any future state interference in land matters in the Builsa area, but also to bring about changes in the customary land law so as to "regulate" and tax capitalist rice farming in the Gbedembilisi Valley. The BTC Land Allocation Committee was given sole authority to deal with land allocation to rice farmers in the Gbedembilisi Valley. This committee imposed acreage ceilings and strict time limits on land leases to rice farmers, allowing a fairer distribution of existing rice land, and reserving the right to reallocate land at a later period should the local community demand it; in addition, it devised a taxation system for capitalist rice farming.

The BTC Land Allocation Committee could have constituted a satisfactory solution to the tensions and conflicts about land and land allocation created by the introduction of capitalist rice farming to the Gbedembilisi Valley. It had the necessary power to limit and monitor closely the acquisition of land by stranger farmers and to allocate land in the interest of local peasant communities. However, its activities were finally thwarted by the combined efforts of the state - which supports capitalist rice farmers (including a good number of farmers closely allied with the regime in power) - and local chiefs and capitalist rice farmers interested in maintaining the status quo. The BTC Land Allocation Committee's failure to "regulate" capitalist rice farming, together with continuous state support of capitalist rice farming, may not only stimulate a further expansion of capitalist rice farming, but also sharpen the simmering conflict between local peasants and capitalist rice farmers over the river valley lands.

Notes

1. See Petition of Bolgatanga Tindaanas to the District Chief Executive, Bolgatanga, in connection with the Bolga lands, dated 10 January 1975 , in file FDC/8/SF.1.

2. Report by the Committee on Ownership of Lands and Position of Tenants in the Northern and Upper Region, 1978 (unpub-
lished). 3. See 1931 Land and Native Rights Ordinance; see also Pogucki
1951.

4. Ghana, Ministry of Planning, Five-Year Development Plan, 1975/76-1979/80, Part II, Accra, 1977, p. 11. 
5. The stool symbolizes chieftainship in Southern Ghana. For an explanation of the term "stool land", see Benneh 1970.

6. See note 2 .

7. See Ghana, Constitution of the Third Republic of Ghana, 1979, article 188, clauses 1-4.

8. NAG-T., ADM 1/457: The problems involved in the development of a backward area and their application to the economic development of the Northern Territories of the Gold Coast (by P. Helps, Ass. DC., NT's, Gold Coast).

9. See Letter from Sandemnab to RC Upper Region, Sandema (BTC), 10 May 1976; Petition by Sandemnab to the Head of State and Chairman of the SMC against the Wellembele-Kuoro Committee's Report and the Subsequent Directives by the RC Upper Region for the Withdrawal of Agricultural Inputs and Machinery from Same Area, Sandema (BTC), June 1976.

10. BYA, Report of Committee Investigating Land Allocation, 1976; and Minutes of Meeting between Farmers and Chiefs at the BTC, Sandema, 4 April 1976.

11. Gbedembilisi Valley Dispute. Short Report by Kuoro E.K.M. Dimbie II, Wellembele-Kuoro and President of the UR House of Chiefs and P.E.R.A. Ayagitam, Chianopio and Member of the UR House of Chiefs.

12. Letter from Sandemnab to RC Upper Region, Sandema (BTC), 10 May, 1976.

13. Letter from Regional Agricultural Officer, Bolgatanga, to RC Upper Region, Bolgatanga, 27 May 1976, ref. no. RAO/UR/LS.2 / vol. 2/224.

14. Report by the Three-Men Delegation sent by the Head of State on the Gbedembilisi Valley Dispute, June 1976.

15. Minutes of the Meeting of the BTC Land Allocation Committee, 10 April 1977.

16. Report of the Administrative Committee on Allocation of Farm Lands in Builsa District, 1977 (unpublished), pp. 58-59. 
References:

AGBOSU, L.K.

1978, Statutory Foundations of Land Administration in the Northern and Upper Regions of Ghana. In Mensah-Brown, A.K., ed., Land Ownership and Registration in Ghana. Kumasi: UST ( $\overline{\mathrm{LARC}}$.

1980, Land Administration in Northern Ghana. Review of Ghana Law 12:104.

AKANKO, P.P.A.

1974, Oral Traditions of Builsa: The Origin and Early History of Atuga's Clan in the Builsa State. History Thesis, Advanced Training College, Winneba.

BENNEH, G.

1970, The Impact of Cocoa Cultivation on the Traditional Land Tenure System of the Akan of Ghana. Ghana Journal of Sociology $6: 43$.

BENNETT, A., and SCHORK, W.

1979, Studies towards a Sustainable Agriculture in Northern Ghana. Heidelberg.

DER, B.G.

1975, Colonial Land Policy in the Northern Territories in the Gold Coast. Universitas (Legon) 4:127.

DUE, J.M.

1971, Efficiency of Resource Use - The Case of the Ghanaian State Rice Farms. East African Journal of Rural Development $4: 77$.

FORTES, $M$.

1945. The Dynamics of Clanship among the Tallensi. London: Oxford University Press.

1949, The Web of Kinship among the Tallensi. London: Oxford University Press.

GOODY, J .

1980, Rice-burning and the Green Revolution in Northern Ghana. Journal of Development Studies 16:136.

HEERMANN, I.

1981, Subsistenzwirtschaft und Marktwirtschaft im Wandel. Hohenschäftlarn: Klaus Renner Verlag. 


\section{CAPITALIST FARMING AND LAND ALLOCATION IN GHANA Piet Konings}

HILL, P.

1970, Studies in Rural Capitalism in West Africa. Cambridge: Cambridge University Press.

HUTCHFUL, E.

1979, A Tale of Two Regimes: Imperialism, the Military and

Class in Ghana. Review of African Political Economy 14:35.

KIMBLE, D.

1963, A Political History of Ghana, 1850-1928. Oxford: Clarendon Press.

KONINGS, $P$

1981a, Capitalist Rice Farming and Peasant Communities in the Builsa Area of Ghana. Unpubl. ms. Leiden: AfrikaStudiecentrum.

1981b, Irrigation and Proletarianisation in Northern Ghana: A Case Study of the Vea and Tono Irrigation Projects in the Upper Region. Unpubl. ms. Leiden: Afrika-Studiecentrum.

1982, State and Class Formation in Cocoa Production in Ahafo (Ghana), Unpubl. ms. Leiden: Afrika-Studiecentrum.

1983, State and Rural Class Formation in Ghana: A Comparative Analysis. Leiden: Afrika-Studiecentrum (to be published by Kegan Paul International, London).

KROEGER, F.

1978, Ubergangsriten im Wandel. Hohenschäftlarn: Klaus Renner Verlag.

1982, Ancestor Worship among the Bulsa of Northern Ghana. Hohenschäftlarn: Klaus Renner Verlag.

LADOUCEUR, P.A.

1979, Chiefs and Politicians: The Politics of Regionalism in Northern Ghana. London: Longman.

MIRACLE, M.P., and SEIDMAN, A.

1968a, State Farms in Ghana. Land Tenure Centre, Madison, Wisconsin.

1968b, Agricultural Co-operatives and Quasi-Co-operatives in Ghana. Land Tenure Centre, Madison, Wisconsin. 
OKOSO-AMAA, K. 1975, Rice Marketing in Ghana. Uppsala: The Scandinavian

PATTERSON, K.D.

1978, River Blindness in Northern Ghana, 1900-1950. In Hartwig, G.W., and Patterson, K.D., eds., Disease in African History. Durham, D.C.: Duke University Press.

PLANGE, Nii-K. 1979, Underdevelopment in Northern Ghana. Review of
African Political Economy nos. 15-16.

POGUCKI, R.J.H.

1951, Report on Land Tenure in Native Customary Law of Coast. Accra: Government Printer. Territories of the Gold

ROURKE, B.E., and SAKYI-GYINAE, S.K.

1972, Agricultural and Urban Wage Rates

Bulletin of Ghana 2 (2nd series) Economic

SHEPHERD, A.W.

1979, The Development of Capitalist Rice Farming in

Northern Ghana. Ph.D. Thesis, University of Cambridge.

In81, Agrarian Change in Northern Ghana: Public Roberts, P., and Williams, Garming and Famine. In Heyer, J., Tropical Africa. London: MacMillan Press-

SCHOTT, R

Bauernvolkes. Köln/Opladen. West eines westafrikanischen . Westdeutscher Verlag.

1977, Sources for a History of the Bulsa in Northern Ghana.
Paideuma 23:141.

Jurisdiction among the Bulsa of Northern State, 21:121.

1980b, Triviales und Transzendentes: Einige Aspekte Berücksichtigung der Bulsa in unter besonderer W. , Franke, M., and Köhler Nord-Ghana. In Fikentscher,

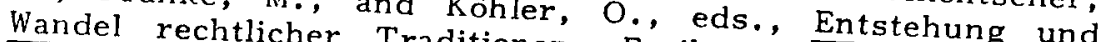
Karl Alber. 


\section{CAPITALIST FARMING AND LAND ALLOCATION IN GHANA}

Piet Konings

THOMAS, R.G.

1973, Forced Labour in British West Africa: The Case of the Northern Territories of the Cold Coast. Journal of African History $14: 79$. 